\title{
3-Ishwarone and 3-Ishwarol, Rare Sesquiterpenes in Essential Oil from Leaves of Peperomia oreophila Hensch.
}

\author{
João Henrique G. Lago, ${ }^{*, a}$ Alberto de Oliveira, ${ }^{b}$ Elsie F. Guimarães ${ }^{c}$ and Massuo J. Kato $^{b}$ \\ ${ }^{a}$ Centro de Ciências e Humanidades, Universidade Presbiteriana Mackenzie, \\ 01302-907 São Paulo-SP, Brazil \\ ${ }^{b}$ Instituto de Química, Universidade de São Paulo, CP 26077, \\ 05513-970 São Paulo-SP, Brazil \\ ${ }^{c}$ Instituto de Pesquisas do Jardim Botânico, Jardim Botânico do Rio de Janeiro, \\ 22460-030 Rio de Janeiro-RJ, Brazil
}

\begin{abstract}
O óleo essencial obtido das folhas de Peperomia oreophila (Piperaceae) foi submetido a fracionamento em gel de sílica. Esse processo de separação resultou em uma fração composta por uma mistura de hidrocarbonetos sesquiterpênicos que foram identificados como $\beta$-elemeno, $\alpha$ ilangeno, $\alpha$-guaieno e $\beta$-selineno. Além desses, também foram identificados o espatulenol e dois sesquiterpenos com raro esqueleto ishwarano: o 3-ishwarol e a 3-ishwarona, sendo esta última, o componente majoritário do óleo bruto (78\% em massa). Uma vez que o álcool foi obtido em quantidade insuficiente para caracterização estrutural, maiores quantidades foram obtidas por meio da redução da cetona original. Os dois sesquiterpenos foram purificados e depois caracterizados por meio de técnicas espectrométricas ( ${ }^{1} \mathrm{H}-{ }^{1} \mathrm{H}$ COSY, HMQC, HMBC e NOESY).
\end{abstract}

The essential oil from Peperomia oreophila leaves (Piperaceae) was submitted to fractionation in silica gel column. This separation procedure yielded a fraction composed of a hydrocarbon sesquiterpene mixture which was identified as $\beta$-elemene, $\alpha$-ylangene, $\alpha$-guaiene and $\beta$-selinene. Besides, spathulenol and two sesquiterpenes with the rare ishwarane skeleton: 3-ishwarol and 3-ishwarone were also identified. 3-ishwarone was the major component of the crude oil (78\% weight). Since the alcohol obtained was not sufficient to allow a complete structural determination, the original ketone was reduced to 3-ishwarol in order to give additional quantities. After the two sesquiterpenes purification, they were characterized by spectrometric techniques $\left({ }^{1} \mathrm{H}-{ }^{1} \mathrm{H}\right.$ COSY, HMQC, HMBC and NOESY).

Keywords: Peperomia oreophila, essential oil, ishwarane sesquiterpenes, 3-ishwarol, 3ishwarone

\section{Introduction}

As part of our ongoing phytochemical research on Brazilian Piperaceae species, we have investigated extracts from Piper and Peperomia species. ${ }^{1-4}$ The genus Peperomia has over 1000 species occurring in the tropics, its leaves have a variety of size and shape and are adapted to moist habitat and dry highlands as well. In despite of the large number of Peperomia species, only a few species have been chemically analyzed and, as a result, amides, chromenes, benzoic acids, lignoids and poliketide

*e-mail: joaolago@iq.usp.br derivatives were isolated..$^{5-7}$ Furthermore, there is only one report on the chemical composition of volatile compounds in Peperomia species, in which phenylpropanoids were identified in $P$. subespatulata. ${ }^{8}$

In this paper, we report the chemical study of essential oil from leaves of $P$. oreophila, including the isolation and structural determination of two sesquiterpenes with a rare skeleton, 3-ishwarol and 3-ishwarone. Despite these sesquiterpenes have previously been described as synthetic products, ${ }^{9}$ in the present article, we describe their first occurrence as natural products. Additionally, complete assignments of the spectral data to 3-ishwarol and 3ishwarone were performed including $2 \mathrm{D}$ NMR $\left({ }^{1} \mathrm{H}-{ }^{1} \mathrm{H}\right.$ COSY, HMQC, HMBC and NOESY) analyses. 


\section{Results and Discussion}

P. oreophila leaves essential oil was analyzed by gas chromatography (GC) and submitted to separation on silica gel column affording 8 fractions that were individually analyzed with GC. Fractions 1 and 2, composed by hydrocarbon sesquiterpenes, were pooled and analyzed with GC/MS, allowing the identification of $\beta$-elemene (1), $\alpha$-ylangene (2), $\alpha$-guaiene (3) and $\beta$ selinene (4). Fraction 7 was constituted by spathulenol (6) according to its NMR spectra. ${ }^{10,11}$

Fraction 5, after purification procedures, yielded the sesquiterpene 5 whose structure was deduced from the IR, MS, and NMR spectral data. The IR spectrum exhibited a strong absorption at $1680 \mathrm{~cm}^{-1}$, indicating the presence of a carbonyl group in its molecular structure. The molecular formula $\mathrm{C}_{15} \mathrm{H}_{22} \mathrm{O}$ was determined with analysis of LREIMS ([M] ${ }^{+} \mathrm{m} / \mathrm{z}, 218$ ) and ${ }^{13} \mathrm{C}$ NMR (BBD and DEPT $135^{\circ}$ ) spectral data, which displayed fifteen signals referring to three methyls, five methylenes, three methines, as well as four quaternary carbons, among which one of carbonyl group. The hydrogen deficiency index to 5 was calculated as five, which in association to the absence of olefinic carbons and the presence of a carbonyl group, suggest a tetracyclic molecule, a quite unusual feature for a sesquiterpene skeleton.

Inspection of NMR data indicated several similar signals to those of ishwarane derivatives, such as 1-methyl- 10-oxo-tetracyclo [7.2.1.0 $\left.0^{2,11} \cdot 0^{4,9}\right]$ dodecane, 8-ishwarone, 8 -ishwarol, and ishwarane which possess four rings in their structures. ${ }^{12,13}$ These similarity associated to the knowledge of the occurrence of ishwarane sesquiterpenoids in Piper alamago, ${ }^{12}$ a Piperaceae species, provided the basis for its determination.

Since the ${ }^{1} \mathrm{H}$ NMR spectrum in $\mathrm{CDCl}_{3}$ showed several overlapped signals at $\delta 1.0-2.5$, this spectrum was recorded in $\mathrm{C}_{6} \mathrm{D}_{6}$ (Table 1). Thus, three methyl groups splitted apart into two quarternary methyl groups at $\mathrm{d} 0.89(\mathrm{~s}, 3 \mathrm{H}), 0.96$ $(\mathrm{s}, 3 \mathrm{H})$ and a secondary one at $\delta 1.25(\mathrm{~d}, J 6.6 \mathrm{~Hz}, 3 \mathrm{H})$ were observed. By using HMQC and HMBC techniques, ${ }^{1} \mathrm{H}$ and ${ }^{13} \mathrm{C}$ signals could be assigned (Table 1 ). The HMQC spectrum showed the hydrogen bearing carbons in structure of 5 which, in association to ${ }^{1} \mathrm{H}-{ }^{1} \mathrm{H}$ COSY spectrum, positioned the carbonyl group at $\mathrm{C}-3$. The HMBC long range correlation between $\mathrm{H}-1$ and $\mathrm{C}-3$, C-9, C-10, C-12, between H-13 and C-1, C-2, C-10, C-11 and between $\mathrm{H}-12$ and $\mathrm{C}-2, \mathrm{C}-4, \mathrm{C}-9, \mathrm{C}-10$ and $\mathrm{C}-11$ determined the partial tricycle moiety of ishwarane skeleton and confirmed the carbonyl group at C-3. These assignments could also be confirmed based on the shielding ( $\gamma$ effect) observed to C-14 methyl group $\left(\delta_{\mathrm{C}}\right.$ 12.0) which only would be possible when carbonyl group is linked at C-3. Correlation between H-7 and C-5, C-9, between $\mathrm{H}-14$ and $\mathrm{C}-3, \mathrm{C}-4, \mathrm{C}-5, \mathrm{C}-9$ and between $\mathrm{H}-5$ and C-4, C-6, C-7, C-9, C-14 and C-15 completed the structural elucidation of this derivative. Thus, based on

Table 1. NMR data for 3-ishwarone (5) (500 and $125 \mathrm{MHz}, \delta, \mathrm{C}_{6} \mathrm{D}_{6}$ )

\begin{tabular}{|c|c|c|c|c|c|}
\hline & ${ }^{1} \mathrm{H}$ (multiplicity, J/Hz) & ${ }^{1} \mathrm{H}-{ }^{1} \mathrm{H}$ COSY* & NOESY & ${ }^{13} \mathrm{C}$ & $\mathrm{HMBC}(\mathrm{H} \rightarrow \mathrm{C})$ \\
\hline 1 & $1.14(\mathrm{dd}, 7.4,2.8)$ & $\mathrm{H}-2, \mathrm{H}-12 \mathrm{~b}$ & - & $29.9(\mathrm{CH})$ & $\mathrm{C}-3, \mathrm{C}-9, \mathrm{C}-10, \mathrm{C}-12$ \\
\hline 2 & $1.53(\mathrm{~d}, 7.4)$ & $\mathrm{H}-1$ & $\mathrm{H}-13$ & $37.9(\mathrm{CH})$ & $\mathrm{C}-4, \mathrm{C}-10, \mathrm{C}-12, \mathrm{C}-13$ \\
\hline 3 & - & - & - & $213.4(\mathrm{C})$ & - \\
\hline 4 & - & - & - & $49.9(\mathrm{C})$ & - \\
\hline 5 & $1.76(\mathrm{dqd}, 12.1,6.6,4.0)$ & H-6a, H-6b, H-15 & H-6b, H-10b, H-15 & $31.8(\mathrm{CH})$ & $\mathrm{C}-4, \mathrm{C}-6, \mathrm{C}-7, \mathrm{C}-9, \mathrm{C}-14, \mathrm{C}-15$ \\
\hline 6 & $\begin{array}{l}\text { a: } 1.02(\mathrm{~m}) \\
\text { b: } 1.23(\mathrm{~m})\end{array}$ & $\begin{array}{l}\text { H-5, H-6b, H-7a, H-7b } \\
\text { H-5, H-6a, H-7a, H-7b }\end{array}$ & $\mathrm{H}-6 \mathrm{~b}$ & $31.5\left(\mathrm{CH}_{2}\right)$ & $\begin{array}{c}\text { C- } 4, \text { C-5, C-8, C-15C-4, } \\
\text { C-5, C-8, C-15 }\end{array}$ \\
\hline 7 & $\begin{array}{l}\text { a: } 1.14(\mathrm{~m}) \\
\text { b: } 1.32(\mathrm{~m})\end{array}$ & $\begin{array}{l}\text { H-6a, H-6b, H-7b, H-8a, H-8b } \\
\text { H-6a, H-6b, H-7a, H-8a, H-8b }\end{array}$ & $\begin{array}{c}\text { H-7b, H-8a } \\
\text { H-7a }\end{array}$ & $23.6\left(\mathrm{CH}_{2}\right)$ & C-5, C-9C-5, C-9 \\
\hline 8 & $\begin{array}{l}\text { a: } 0.89(\mathrm{~m}) \\
\text { b: } 1.33(\mathrm{~m})\end{array}$ & $\begin{array}{l}\text { H-7a, H-7b, H-8b } \\
\text { H-7a, H-7b, H-8a }\end{array}$ & $\begin{array}{c}\text { H-7a, H-8b, H-14 } \\
\text { H-8a }\end{array}$ & $32.2\left(\mathrm{CH}_{2}\right)$ & $\begin{array}{l}\text { C-4, C-6, C-7, C-9, C-10, C-12 } \\
\text { C-4, C-6, C-7, C-9, C-10, C-12 }\end{array}$ \\
\hline 9 & - & - & - & $43.1(\mathrm{C})$ & - \\
\hline 10 & $\begin{array}{l}\text { a: } 1.98(\mathrm{~d}, 12.4) \\
\text { b: } 0.97(\mathrm{~d}, 12.4)\end{array}$ & $\begin{array}{l}\text { H-10a } \\
\text { H-10b }\end{array}$ & $\begin{array}{l}\mathrm{H}-5, \mathrm{H}-10 \mathrm{~b} \\
\mathrm{H}-10 \mathrm{a}\end{array}$ & $39.5\left(\mathrm{CH}_{2}\right)$ & $\begin{array}{l}\text { C-2, C-4, C-9, C-11, C-12 } \\
\text { C-2, C-4, C-9, C-11, C-12 }\end{array}$ \\
\hline 11 & - & - & - & $30.0(\mathrm{C})$ & - \\
\hline 12 & $\begin{array}{l}\text { a: } 1.65(\mathrm{~d}, 12.4) \\
\text { b: } 1.10(\mathrm{dd}, 12.4 ; 2.8)\end{array}$ & $\begin{array}{c}\text { H-12b } \\
\text { H-1, H-12a }\end{array}$ & $\begin{array}{c}\mathrm{H}-12 \mathrm{~b}, \mathrm{H}-14 \\
\mathrm{H}-12 \mathrm{a}\end{array}$ & $35.1\left(\mathrm{CH}_{2}\right)$ & $\begin{array}{l}\text { C-2, C-4, C-9, C-10, C-11 } \\
\text { C-2, C-4, C-9, C-10, C-11 }\end{array}$ \\
\hline 13 & $0.96(\mathrm{~s})$ & - & $\mathrm{H}-2$ & $19.5\left(\mathrm{CH}_{3}\right)$ & $\mathrm{C}-1, \mathrm{C}-2, \mathrm{C}-10, \mathrm{C}-11$ \\
\hline 14 & $0.89(\mathrm{~s})$ & - & H-8a, H-12a & $12.0\left(\mathrm{CH}_{3}\right)$ & C-3, C-4, C-5, C-9 \\
\hline 15 & $1.25(\mathrm{~d}, 6.6)$ & $\mathrm{H}-5$ & $\mathrm{H}-5$ & $17.7\left(\mathrm{CH}_{3}\right)$ & $C-4, C-5, C-6$ \\
\hline
\end{tabular}

*registered in $\mathrm{CDCl}_{3}$. 
the above evidence, the structure of $\mathbf{5}$ was established as 3-ishwarone.

The ${ }^{1} \mathrm{H}$ NMR spectrum of purified fraction $7\left(\mathrm{C}_{6} \mathrm{D}_{6}\right)$ showed three methyl groups at $\delta 0.89$ (d, $J=6.6 \mathrm{~Hz}), 0.74$ (s), $1.12(\mathrm{~s})$ and several signals at $\delta 0.5-2.0$, similar to those observed to 3-ishwarone. However, the triplet at $\delta$ $1.53(J=7.4 \mathrm{~Hz})$, assigned to $\alpha$-carbonyl hydrogen $\mathrm{H}-2$, was not observed but a broad singlet at $\delta 3.66(1 \mathrm{H})$ instead, suggesting the presence of an alcohol derivative (7). As the amount of this compound was not sufficient to determine the structure, it was produced by reduction of ketone derivative (5), followed by GC, GC/MS, IR and NMR analysis. Therefore, compound 5 (35 mg) was treated with $\mathrm{NaBH}_{4}$ in $\mathrm{THF} / \mathrm{MeOH}$ to afford the sesquiterpene 7 (35 mg). Analysis of the IR spectrum with a broad band at $v_{\max } 3373 \mathrm{~cm}^{-1}$ (hydroxyl group) in association to LREIMS, which showed the molecular ion-peak at $\mathrm{m} / z 220 \mathrm{Da}$, compatible with molecular formula $\mathrm{C}_{15} \mathrm{H}_{24} \mathrm{O}$, was indicative of the successful of this reduction reaction. The ${ }^{1} \mathrm{H}$ NMR spectrum $\left(\mathrm{C}_{6} \mathrm{D}_{6}\right)$ of 7 was identical to that observed previously to the alcohol derivative isolated from the essential oil indicating the same structure to these two compounds. The ${ }^{13} \mathrm{C}$ NMR spectrum of 7 (BBD and DEPT $\left.135^{\circ}\right)$ showed 15 signals in which three methyl groups $(\delta$ $20.2,16.7$ and 9.0), five methylene groups ( $\delta 38.9,35.7$, $33.9,30.7$ and 24.2), four methine groups $(\delta 73.9,38.6$, 28.4 and 23.0) and three quaternary carbons $(\delta 43.5,41.4$ and 22.4). As suggested previously, the occurrence of an oxygenated sesquiterpene was confirmed by the signal at $\delta$ $73.9(\mathrm{CH})$ assigned to carbinolic C-3. The hydrogen bearing carbon signals were assigned by HMQC spectrum and showed cross-peak between C-3 and H-3 at $\delta 3.66$ (broad singlet). HMBC spectrum showed correlations between $\mathrm{H}-$ 3 and C-1, C-5, C-9, C-11 and C-14, thus confirming the structure of 3-ishwarol. In order to determine the relative stereochemistry of C-3, the NOESY spectrum of 7 was recorded (Table 2) which showed cross-peaks between $\mathrm{H}$ 3 and H-5, H-10a and H-15, between H-14 and H-8a, H$12 \mathrm{a}$ and between $\mathrm{H}-5$ and $\mathrm{H}-10 \mathrm{a}, \mathrm{H}-3$. Therefore, the relative configuration of C-3 was determined as $\mathrm{R}^{*}$. Finally, the co-injection of the synthetic 3-ishwarol with that isolated from the crude oil provided conclusive evidence to confirm the structure of natural sesquiterpene 7 .

Thus, after characterization of compounds 5 and $\mathbf{7}$ with NMR techniques, the main compounds of the crude essential oil from leaves of Peperomia oreophila were identified as showed in Table 3.

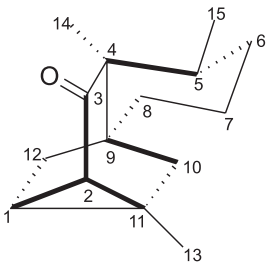

5

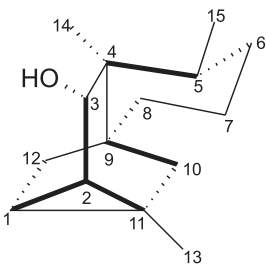

7
The occurrence of 3-ishwarone as major derivative in $P$. oreophila leaves crude oil was detected using NMR experiments, before chromatographic procedures. As these data suggested the occurrence of an unusual compound in essential oils, the chromatographic separation was

Table 2. NMR data for 3-ishwarol (7) (500 and $125 \mathrm{MHz}, \delta, \mathrm{C}_{6} \mathrm{D}_{6}$ )

\begin{tabular}{|c|c|c|c|c|c|}
\hline & ${ }^{1} \mathrm{H}$ (multiplicity, $J / \mathrm{Hz}$ ) & ${ }^{1} \mathrm{H}-{ }^{1} \mathrm{H} \mathrm{COSY}$ & NOESY & ${ }^{13} \mathrm{C}$ & $\mathrm{HMBC}(\mathrm{H} \rightarrow \mathrm{C})$ \\
\hline 1 & $0.82(\mathrm{dd}, 7.1,2.9)$ & $\mathrm{H}-2, \mathrm{H}-12 \mathrm{~b}$ & $\mathrm{H}-2$ & $23.0(\mathrm{CH})$ & C-3, C-9, C-10, C-12, C-13 \\
\hline 2 & $0.56(\mathrm{~d}, 7.1)$ & $\mathrm{H}-3$ & H-1, H-3, H-13 & $28.4(\mathrm{CH})$ & $\mathrm{C}-4, \mathrm{C}-10, \mathrm{C}-12, \mathrm{C}-13$ \\
\hline 3 & $3.66(\mathrm{sl})$ & $\mathrm{H}-2$ & H-2, H-5, H-10a, H-15 & $73.9(\mathrm{CH})$ & C-1, C-5, C-9, C-11, C-14 \\
\hline 4 & - & - & - & $41.4(\mathrm{C})$ & - \\
\hline 5 & $1.33(\mathrm{~m})$ & H-6a, H-6b, H-15 & H-3, H-10a, H-15 & $38.6(\mathrm{CH})$ & C-3, C-4, C-6, C-7, C-14, C-15 \\
\hline 6 & $\begin{array}{c}\text { a: } 1.21(\mathrm{~m}) \\
\text { b: } 1.04(\mathrm{dd}, 12.0 ; 3.9)\end{array}$ & $\begin{array}{l}\text { H-5, H-6b, H-7a, H-7b } \\
\text { H-5, H-6a, H-7a, H-7b }\end{array}$ & $\mathrm{H}-6 \mathrm{~b}$ & $30.7\left(\mathrm{CH}_{2}\right)$ & $\begin{array}{l}\text { C-4, C-5, C-7, C-8, C-15 } \\
\text { C-4, C-5, C-7, C-8, C-15 }\end{array}$ \\
\hline 7 & $\begin{array}{l}\text { a: } 1.38(\mathrm{~m}) \\
\text { b: } 1.26(\mathrm{~m})\end{array}$ & $\begin{array}{l}\text { H-6a, H-6b, H-7b, H-8a, H-8b } \\
\text { H-6a, H-6b, H-7a, H-8a, H-8b }\end{array}$ & $\mathrm{H}-8 \mathrm{~b}$ & $24.2\left(\mathrm{CH}_{2}\right)$ & $\begin{array}{l}\text { C-5, C-6, C-8, C-9 } \\
\text { C-5, C-6, C-8, C-9 }\end{array}$ \\
\hline 8 & $\begin{array}{l}\text { a: } 1.51(\mathrm{~m}) \\
\text { b: } 0.95(\mathrm{~m})\end{array}$ & $\begin{array}{l}\text { H-7a, H-7b, H-8b } \\
\text { H-7a, H-7b, H-8a }\end{array}$ & $\begin{array}{l}\mathrm{H}-8 \mathrm{~b}, \mathrm{H}-14 \\
\mathrm{H}-8 \mathrm{a}, \mathrm{H}-7 \mathrm{a}\end{array}$ & $33.9\left(\mathrm{CH}_{2}\right)$ & $\begin{array}{l}\text { C-6, C-7, C-9, C-10, C-12 } \\
\text { C-6, C-7, C-9, C-10, C-12 }\end{array}$ \\
\hline 9 & - & - & - & $43.5(\mathrm{C})$ & - \\
\hline 10 & $\begin{array}{l}\text { a: } 1.89(d, 12.0) \\
\text { b: } 0.87(d, 12.0)\end{array}$ & $\begin{array}{l}\text { H-10b } \\
\text { H-10a }\end{array}$ & $\begin{array}{c}\mathrm{H}-3, \mathrm{H}-5, \mathrm{H}-10 \mathrm{~b} \\
\mathrm{H}-10 \mathrm{a}\end{array}$ & $38.9\left(\mathrm{CH}_{2}\right)$ & $\begin{array}{l}\text { C-2, C-4, C-8, C-9, C-11, C-12, C-13 } \\
\text { C-2, C-4, C-8, C-9, C-11, C-12, C-13 }\end{array}$ \\
\hline 11 & - & - & - & $22.4(\mathrm{C})$ & - \\
\hline 12 & $\begin{array}{c}\text { a: } 1.79(\mathrm{~d}, 12.0) \\
\text { b: } 1.12(\mathrm{dd}, 12.0 ; 2.7)\end{array}$ & $\begin{array}{c}\text { H-12b } \\
\text { H-1, H-12a }\end{array}$ & $\begin{array}{c}\mathrm{H}-12 \mathrm{~b}, \mathrm{H}-14 \\
\mathrm{H}-12 \mathrm{a}\end{array}$ & $35.7\left(\mathrm{CH}_{2}\right)$ & $\begin{array}{l}\text { C-1, C-2, C-4, C-8, C-9, C-10 } \\
\text { C-1, C-2, C-4, C-8, C-9, C-10 }\end{array}$ \\
\hline 13 & $1.12(\mathrm{~s})$ & - & $\mathrm{H}-2$ & $20.2\left(\mathrm{CH}_{3}\right)$ & C-2, C-10, C-11 \\
\hline 14 & $0.74(\mathrm{~s})$ & - & $\mathrm{H}-8 \mathrm{a}, \mathrm{H}-12 \mathrm{a}$ & $9.0\left(\mathrm{CH}_{3}\right)$ & C-3, C-4, C-5, C-9 \\
\hline 15 & $0.89(\mathrm{~d}, 6.6)$ & H-5 & H-3, H-5 & $16.7\left(\mathrm{CH}_{3}\right)$ & C-4, C-5, C-6 \\
\hline
\end{tabular}


Table 3. Chemical composition of the essential oil from leaves of $P$. oreophila

\begin{tabular}{lccc}
\hline component & $\mathrm{RR}_{\mathrm{t}} / \mathrm{s}$ & $\mathrm{RI}$ & percentage \\
\hline$\beta$-elemene (1) & 1170 & 1375 & 1.4 \\
$\alpha$-ylangene (2) & 1212 & 1322 & 0.8 \\
$\alpha$-guaiene (3) & 1284 & 1491 & 2.4 \\
$\beta$-selinene (4) & 1332 & 1608 & 0.8 \\
3-ishwarone (5) & 1674 & 1807 & 78.2 \\
spathulenol (6) & 1728 & 1825 & 2.6 \\
3-ishwarol (7) & 1926 & 2020 & 0.8 \\
TOTAL & & & 87.0 \\
\hline
\end{tabular}

necessary to allow the identification of this compound, since it was not identified with GC/MS as well. Additionally, the spectrometric analysis of the fractions obtained with chromatographic separation of crude hexane extract showed the presence of 3-ishwarone, indicating that this compound occurs also in high amount in the apolar extract from leaves. Thus, the hypothesis of formation of this compound as artifact by hydrodistillation and/or chromatographic procedures must be discarded.

Sesquiterpenes containing the ishwarane skeleton are quite rare. These derivatives were detected previously only in Aristolochiaceae, ${ }^{9,14-16}$ Annonaceae, ${ }^{17}$ Bixaceae $^{18}$ and Piperaceae $^{12}$ species.

\section{Experimental}

\section{General procedures}

Silica gel (Merck, 230-400 mesh) was used for column chromatographic separations while silica gel $60 \mathrm{PF}_{254}$ (Merck) was used for analytical $(0.25 \mathrm{~mm})$ and prepared. TLC $(1.0 \mathrm{~mm})$. Optical rotations were measured in a digital polarimeter JASCO DIP-370 (Na filter, $\lambda=588 \mathrm{~nm}$ ). IR spectra were measured in $\mathrm{KBr}$ pellets and $\mathrm{NaCl}$ film in a Perkin-Elmer Infrared Spectrometer model 1750. LREIMS spectra were measured at $70 \mathrm{eV}$ on a HP 5990/5988A spectrometer. ${ }^{1} \mathrm{H}$ and ${ }^{13} \mathrm{C}$ NMR spectra were recorded at 500 and $125 \mathrm{MHz}$ in a Brüker DRX-500 spectrometer. $\mathrm{CDCl}_{3}$ and $\mathrm{C}_{6} \mathrm{D}_{6}$ (Aldrich) was used as solvent and TMS as internal standard. Chemical shifts were reported in $\delta$ units (ppm) and coupling constants $(J)$ in Hz. GC data was obtained by a Hewlett-Packard 5890 series II equipped with FID detector and a capillary column HP-5, crosslinked 5\% phenyl in methyl silicone $(30 \mathrm{~m} \times 0.32 \mathrm{~mm}$; film tickness $0.25 \mathrm{~mm}$ ), an automatic injector (HP 7673) and electronic integrator (HP 3396A) were used. The temperature programming started at $100{ }^{\circ} \mathrm{C}(2 \mathrm{~min}), 100-240{ }^{\circ} \mathrm{C}$ at $5{ }^{\circ} \mathrm{C} \mathrm{min}{ }^{-1}$, then isothermal at $240{ }^{\circ} \mathrm{C}$ (5 min). The injector and detector temperatures were $180{ }^{\circ} \mathrm{C}$ and $260{ }^{\circ} \mathrm{C}$, respectively, and helium was used as the carrier gas. Quantitative data was obtained from electronic integration of the area percent data without the use of and internal standard or correction factors. GC/MS analysis were carried out in as EIMS 70 eV Hewlet-Packard HP-5973 coupled with a Hewlet-Packard HP-6890 with DB-5 column (30 m $\times 0.25$ $\mathrm{mm}$, film tickness $0.25 \mathrm{~mm}$ ) using the same temperature programming conditions above described. The identification of the compounds, except $\mathbf{5}$ and 7, was performed by comparing the mass spectra and the retention index, ${ }^{19}$ which were determined relatively to the retention time of a series of n-alkanes, with those of authentic samples.

\section{Plant material}

Peperomia oreophila Hensch. leaves were collected in Poços de Caldas, Minas Gerais, Brazil in May/2002. Plant material identification was performed by Dr. Elsie F. Guimarães. A voucher specimen (Kato-225) was deposited in the Herbarium of Instituto de Botânica, São Paulo, Brazil.

\section{Extraction and isolation}

The fresh leaves of $P$. oreophila (245 g) were subjected to hydrodistillation during four hours using a Clevengertype apparatus to give $120.1 \mathrm{mg}$ of yellow pale crude oil $(\sim 0.05 \%)$, which were immediately submitted to GC and GC/MS analysis. Part of this material (100.0 mg) was submitted to flash chromatography on silica gel eluted with $\mathrm{CH}_{2} \mathrm{Cl}_{2}(100 \mathrm{~mL})$ and gradient of $\mathrm{CH}_{2} \mathrm{Cl}_{2}-\mathrm{MeOH}$ 95:5 (50 $\mathrm{mL})$ and 9:1 (50 mL) to afford eight fractions (15 mL each) which were analyzed with gas chromatography. ${ }^{20}$ Fraction 1 (10.2 mg), eluted with $\mathrm{CH}_{2} \mathrm{Cl}_{2}$, was subjected to analysis with GC/MS to allowed the identification of $\beta$-elemene, $\alpha$-ylangene, $\alpha$-guaiene and $\beta$-selinene. GC chromatograms of fractions 2-4 showed to be composed by complex mixtures of sesquiterpenes. ${ }^{21}$ Fraction 5 (62.1 mg), eluted with $\mathrm{CH}_{2} \mathrm{Cl}_{2}-\mathrm{MeOH}$ 95:5, and 6 (9.0 mg), eluted with $\mathrm{CH}_{2} \mathrm{Cl}_{2}-\mathrm{MeOH}$ 9:1, showed GC chromatograms with intense peaks at $\mathrm{RR}_{\mathrm{t}}=1674$ and 1926 seconds, respectively. Thus, these fractions were individually submitted to prep. TLC on Si-gel eluted with $\mathrm{CH}_{2} \mathrm{Cl}_{2}$ (twice) affording, respectively, $5(46.3 \mathrm{mg})$ and $7(0.5 \mathrm{mg})$. Fraction 7, eluted with $\mathrm{CH}_{2} \mathrm{Cl}_{2}-\mathrm{MeOH} 9: 1$, was composed of nearly pure spathulenol (3.1 mg).

\section{Reduction of 3-ishwarone}

To a stirred solution of 5 (35 mg, $0.16 \mathrm{mmol})$ in THF (5 mL) was added $\mathrm{NaBH}_{4}(7.6 \mathrm{mg}, 0.2 \mathrm{mmol})$ dissolved 
in $\mathrm{MeOH}(1 \mathrm{~mL})$. After $4 \mathrm{~h}$, the reaction mixture was partitioned between EtOAc and saturated $\mathrm{NaCl}$ solution. The combined organic soluble solution was dried $\left(\mathrm{MgSO}_{4}\right)$ and evaporated in vacuo to afford 3-ishwarol 7 (35 mg, 99.4\%) as a white amorphous solid, which was obtained without further purification.

\section{3-ishwarone (5)}

White amorphous solid. $[\alpha]_{\mathrm{D}}{ }^{30}+111.1^{\circ}$ (c 0.35 , $\mathrm{CHCl}_{3}$ ). IR (KBr) $v_{\max } / \mathrm{cm}^{-1}: 3033$ (cyclopropane ring), 2929 (C-H), 1680 (C=O), 1450, 1245, 899. LREIMS (70 eV) $m / z$ (rel. int.) $218[\mathrm{M}]^{+}(17), 200(5), 190(8), 185(4)$, 175(6), 161(14), 147(29), 133(14), 119(40), 106(83), 93(100), 85(50), 77(39), 67(31), 55(84), 41(93). ${ }^{1} \mathrm{H}$ and ${ }^{13} \mathrm{C}$ NMR: see Table 1 (spectra recorded in $\mathrm{C}_{6} \mathrm{D}_{6}$ ).

\section{3-ishwarol (7)}

White amorphous solid. $[\alpha]_{\mathrm{D}}^{30}-394.5^{\circ}\left(c 0.26, \mathrm{CHCl}_{3}\right)$. IR (film) $v_{\max } / \mathrm{cm}^{-1}: 3373(\mathrm{OH}), 2934$ (cyclopropane ring), 2857 (C-H), 1675, 1384, 1004 (C-O), 932. LREIMS (70 eV) $m / z$ (rel. int.): $220[\mathrm{M}]^{+}(10), 202(5), 192(4), 187(4)$, 177(2), 163(6), 145(7), 131(15), 118(100), 108(52), 105(40), 93(63), 91(33), 81(20), 79(20), 77(20), 69(12), 67(17), 55(34), 41(44). ${ }^{1} \mathrm{H}$ and ${ }^{13} \mathrm{C}$ NMR: see Table 2 (spectra recorded in $\mathrm{C}_{6} \mathrm{D}_{6}$ ).

\section{Acknowledgments}

The authors are grateful to CNPq and FAPESP for the financial support.

\section{References}

1. Lago, J.H.G.; Ramos, C.S.; Casanova, D.C.C.; Morandim, A.A.; Bergamo, D.C.B; Furlan, M.; Cavalheiro, A.J.; Bolzani, V.S., Young, M.C.M.; Guimarães, E.F.; Kato, M.J.; J. Nat. Prod. 2004, 67, 1783.

2. Martins, R.C.C.; Lago, J.H.G.; Albuquerque, S.; Kato, M.J.; Phytochemistry 2003, 64, 667 .
3. Danelutte, A.P.; Lago, J.H.G.; Young, M.C.M.; Kato, M.J.; Phytochemistry 2003, 64, 555.

4. Salazar, K.J.M.; Paredes, G.E.D.; Lluncor, L.R.; Young, M.C.M.; Kato, M.J.; Phytochemistry 2005, 66, 573.

5. Mahiou, V.; Roblot, F.; Hocquemiller, A., Cavè, A.; J. Nat. Prod. 1995, 58, 324.

6. Govindachari, T.R.; Kumari, K.G.N.; Partho, P.D.; Phytochemistry 1998, 49, 2129.

7. Soares, M.G.; Felippe, A.P.V.; Guimarães, E.F.; Kato, M.J.; Ellena, J.; Doriguetto, A.C.; J. Braz. Chem. Soc. 2006, 17, 1205.

8. Diaz, A.M.P.; Diaz, P.P.; Cardoso, H.; Planta Med. 1988, 54, 92.

9. Fuhrer, H.; Ganguly, A.K.; Gopinath, K.W.; Govindachari, T.R.; Nagarajan, K.; Pai, B.R.; Parthasarathy, P.C.; Tetrahedron 1970, 26, 2371.

10. Brochini, C.B.; Roque, N.F.; J. Braz. Chem. Soc. 2000, 11, 361.

11. Goldsby, G.; Burke, B.A.; Phytochemistry 1987, 26, 1059.

12. Achenbach, H.; Grob, J.; Portecop, J.; Planta Med. 1984, 50, 528.

13. Cory, R.M.; Stothers, J.B.; Org. Mag. Res. 1978, 11, 5, 252.

14. Ganguly, A.K.; Gopinath, K.W.; Govindachari, T.R.; Nagarajan, K.; Pai, B.R.; Parthasarathy, P.C.; Tetrahedron Lett. 1969, 133.

15. Govindachari, T.R.; Mohamed, P.A.; Parthasarathy, P.C.; Tetrahedron 1970, 26, 614

16. Govindachari, T.R.; Nagarajan, K.; Parthasarathy, P.C.; Chem. Comm. 1969, 823.

17. Teng, L.C.; DeBardeleben J.F.; Experimentia, 1971, 27, 14.

18. Lawrence, B.M.; Hogg, J.W.; Phytochemistry 1973, 12, 2995.

19. Adams, R.P.; Identification of Essential Oils by Ion Trap Mass Spectroscopy, Academic Press: San Diego, 1995.

20. Brochini, C.B.; Nuñez, C.V.; Moreira, I.C.; Roque, N.F.; Chaves, M.H.; Martins, D.; Quim. Nova 1999, 1, 37.

21. Patitucci, M.L; Veiga Jr., V.F.; Pinto, A.C.; Zoghbi, M. das G.B.; Silva, J.R.A.; Quim. Nova 1995, 18, 262.

Received: June 12, 2006 Web Release Date: May 17, 2007

FAPESP helped in meeting the publication costs of this article. 